\title{
The role of agency beliefs in transition: Commentary to the Special Section
}

\author{
Grazyna Wieczorkowska and \\ Jerzy Wierzbinski
}

Warsaw University, Poland

These four papers together offer a fairly rare satisfaction, at least in the social sciences: First, they deal with the same general problem, the relationship between agentic beliefs and achievement, mostly educational or occupational. Second, the data are from different samples in different societies undergoing different kinds of sociopolitical and economic change and they are are analysed by a variety of methods. Finally, mirabile dictu, their findings agree on the general nature of the relationship between agency and achievement, namely, it is to a considerable degree reciprocal-agentic beliefs influence achievement, and achievement, especially success, influences agentic beliefs. In addition to demonstrating the generality of this effect, they present other findings that suggest basic similarities between rather different social systems. For instance, Schoon (2007, this issue) shows that a child's education in the UK is largely determined by his/ her parents' education. Despite 50 years of socialism, with its special laws making it easy for working-class children to enter university, this is just as true in Poland. To illustrate, Cichomski (2004) found that among citizens of Warsaw who only completed primary school, nearly half had fathers who also had no more than a primary school education, whereas less than $10 \%$ had fathers who were university graduates. Similarly, Diewald (2007, this issue) finds that agentic Germans see their successes as dispositional (due to personal effort and skill), and failures as situational (due to circumstances beyond anyone's control), an effect that is observed in many different societies and that follows directly from attribution theory.

\author{
Eugene Burnstein \\ University of Michigan, Ann Arbor, MI, USA and \\ Warsaw School of Social Psychology, Poland
}

Equally interesting are the cross-national differences. For example, Evans (2007, this issue) demonstrated that the level of educational and occupational success varies from one country to another depending on the range of different kinds of education and jobs the social system makes available to members; Schoon (2007, this issue) observed comparable differences in predictors of success as a function of the cohort. Taken together, these findings imply that in societies undergoing social change, cohort differences in achievement are likely because the range of opportunities afforded to individuals early in the process of change is different from that afforded later on. For instance, the best predictor of adult social status for disadvantaged individuals born in 1958 was their teenage educational aspirations; however, for disadvantaged youths born in 1970 the best predictor of adult social status was exam performance. This suggests that the former cohort had better opportunities; that is, a larger number of career options were available to these individuals, and thus, success depended less on the demonstration of academic competence than it did in the latter cohort. Under these conditions, processes mediating between individual agentic beliefs and educational or occupational outcomes may be critical in explaining cohort differences in the agency-achievement relationship. In Poland, for instance, the number of different kinds of schooling or careers available to individuals entering the labour market prior to the transition to a market economy was relatively small compared to the range available to those entering the labour market several years later after the transition. With this in mind we attempted to predict successful adaptation to the transition taking into

Correspondence should be addressed to Grazyna Wieczorkowska, Faculty of Psychology, Warsaw University, Stawki 5/3, 00183 Warszawa, Poland. (E-mail: gw@uw.edu.pl). 
account (1) changes in the options available to individuals in a variety of domains, not only education and careers but also consumer goods, vacation packages, and the like; and (2) individual differences in decision style, that is, the person's characteristic way of deciding which of the available options in a particular domain are acceptable or worth pursuing. Our analysis then examined the effect of the interaction of these two factors on how satisfied the person was with his/ her standard of living, financial situation, etc. now compared to that under socialism. Two polar opposite decision styles were considered: (1) Interval strategists are individuals who aren't choosy; they are characteristically willing to settle for any one of a large number of options (types of education, jobs, consumer goods, vacation packages, etc.) as "good enough". (2) In contrast, point strategists are choosy; they characteristically accept only a narrow range of options, often rejecting all but one (Wieczorkowska \& Burnstein, 1999, 2000, 2002; Wieczorkowska-Nejtardt, 1998).

The theory of agency outlined in the four papers suggests that an interval strategy is likely to be associated with weak agentic beliefs, and a point strategy with strong agentic beliefs. If this is so, then based on our research it follows that weak agentic beliefs are more adaptive during those stages of a transition in which options are scarce, and strong agentic beliefs more adaptive when options are plentiful, although the latter probably holds primarily for those with sufficient financial, educational, or other resources to take advantage of the change. Thus, in a socialist economy, when job hunting, deciding on an education, or purchasing consumer goods, interval strategists avoid the frustration and other costs of the prolonged, often fruitless search that point strategists are bound to incur. In a market economy, however, the point strategists, because they are discriminating and unwilling to consider more than one or a few options as worth pursuing, avoid the interval strategist's fate, namely, settling for an inferior kind of education, job, or product when something much better is available. Indeed, we (Wieczorkowska \& Burnstein, 2004a, b) find that point compared to interval strategists do feel a significantly greater increase in self-efficacy after the transition to a market economy.

These papers also illustrate the difficulty of constructing indices of the complex cognitive and affective processes assumed by agency theory using survey data, as well as the problems that arise when these processes are ignored. For example, in Titma, Tuma, and Roots' (2007, this issue) analysis the two psychological variables, self-ratings of organizational skills and leadership ability, produce skewed distributions and, as a result, are useless as predictors. Agency is a psychological state or a characteristic of the mind with a number of antecedents and consequent processes; conceptually, these are mediating operations having to do with self-assessments ("Do I have sufficient resources, skills, etc.?") and assessments of the situation ("What are the opportunities, the barriers?"), among other things, that need to be taken into account when attempting to predict individual actions and achievements, as agency theory does. This may be especially important during transitions when both self and situations are in flux. The sociological variables used in these papers are clearly too distal and gross to explain agency effects. More importantly, by leaving mediation processes unspecified, they are not reliable (and, under some conditions, not even valid) indices of agency.

We should note that Evans (2007, this issue) does describe several interesting transition behaviours - forms of purposive styles that could be candidates for mediating processes. She called these styles (1) strategic, (2) step by step, (3) taking chances, and (4) wait and see. However, it remains unclear what specific style is associated with a particular degree of agency, the extent to which the styles are mutually exclusive or, if not, what combinations are likely. For example, a step-bystep strategist could be a person who is a careful planner, who lays out each "step" in the achievement sequence and represents in his/her mind the series of subgoals he or she has to achieve (the "steps" in step by step). In short, she or he takes into account the situational contingencies likely to arise and how to overcome them to arrive at a final goal. But if this individual does have a final goal, why isn't he or she also categorized as "strategic"? Alternatively, the person does not establish his/her own final goal but instead accepts as "good enough" the traditional goal(s) society offers and arrives at the latter via the traditional "steps." Is she or he a "strategic" type? Similarly, "take a chance" may imply a risk-taker. But the risk can be either reasonable, with an acceptable probability of success given the person's ability, or unreasonable, a dream far beyond his/her abilities. The reasonable risk-taker may plan carefully (again, step by step); the dreamer doesn't, but simply "tosses the dice." Are both "take a chance" types? Also, how does realism in planning, by taking into account situational contingencies - the unpredictable but not unlikely events affecting goal achievement - enter into this analysis? 
Agency beliefs often seem to be not much more than a person's overall feeling of optimism or pessimism about goal achievement. Presumably it influences how she or he decides which goals to pursue, but how does it do this? To explain the interaction between transition stages and agentic beliefs you should know, first, how individuals assess their abilities and motivation as well as the situational affordances; and, second, how individuals decide on a particular decision strategyunder what conditions are they flexible enough to switch from one strategy to the other even though it may not be the strategy they characteristically prefer? This raises an additional conceptual issue critical for agency theory: Are agency beliefs domain-specific or domain-general? These, of course, do not need to be mutually exclusive. People can have a belief about their general or overall (domain-general) agentic prowess that is relatively independent of how they assess their ability to control the outcome in a particular domain. In any event, until such conceptual issues are resolved, measuring agentic beliefs is problematic and the explanatory value of the theory is limited.

\section{REFERENCES}

Cichomski, B. (2004). Zróżnicowanie społeczne mieszkańców Warszawy z perspektywy porównawczej. In J. Grzelak \& T. Zarycki (Eds.), Społeczna mapa Warszawy. Interdyscyplinarne studium metropolii warszawskiej. Warszaw, Poland: Scholar.

Diewald, M. (2007). Agency or constraint? The mutual shaping of control beliefs and working lives in East
Germany after 1989. International Journal of Psychology, 42, 77-84.

Evans, K. (2007). Concepts of bounded agency in education, work, and the personal lives of young adults. International Journal of Psychology, 42, 85-93.

Schoon, I. (2007). Adaptations to changing times: Agency in context. International Journal of Psychology, 42, 94-101.

Titma, M., Tuma, N. B., \& Roots, A. (2007). Adolescent agency and adult economic success in a transitional society. International Journal of Psychology, 42, 102-109.

Wieczorkowska, G., \& Burnstein, E. (1999). The role of search costs and screening strategies in social change: Adapting to the transition from socialism to capitalism in Poland. Psychological Science, 10, 98-105.

Wieczorkowska, G., \& Burnstein, E. (2000). Monitoring adaptation to social change: Research at the Institute for Social Studies. In J. A. Bargh \& D. K. Apsley (Eds.), Unraveling the complexities of social life (pp. 155-172). Washington, DC: APA.

Wieczorkowska, G., \& Burnstein, E. (2002). The adaptive value of interval goal-setting strategies during social change in Poland. In T. Klonowicz \& G. Wieczorkowska (Eds.), Social change: Adaptation and resistance (pp.97-116). Warsaw, Poland: WISS.

Wieczorkowska, G., \& Burnstein, E. (2004a). Hunting for a job: How individual differences in foraging strategies influence the length of unemployment. Group Processes and Intergroup Relations, 4, 305-317.

Wieczorkowska, G., \& Burnstein, E. (2004b). Individual differences in adaptation to social change. International Journal of Sociology, 34, 83-99.

Wieczorkowska-Nejtardt, G. (1998). Inteligencja motywacyjna: madre strategie wyboru celu i sposobu dzialania [Motivational intelligence: Smart goal setting and action strategies]. Warsaw, Poland: WISS. 